\title{
Beds on the Early Modern Stage
}

\begin{abstract}
Bed scenes remind us how little we know about staging practices in early modern London playhouses. Stage directions often say that a bed was 'discovered' but not where or how. And if it had curtains, were they on the bed or over an opening in the tiring house wall? Was the bed a four-poster, even though such a structure would have blocked sightlines and been cumbersome? Given the extra staging demands bed scenes entailed, why did playwrights include them? This study focuses on these and related matters with reference to all bed scenes in plays written between 1580 and 1642.
\end{abstract}

Bed scenes in early modern plays provide sobering reminders of how little we actually know about staging practices in the London playhouses of the time. And the stage directions for these scenes are at the heart of the problem because they provide insufficient information for confident interpretation four centuries later. Directions for bed scenes often say that a bed was 'discovered' but not where or how. And, if a direction includes a reference to curtains, were they on the bed or hanging over an opening in the tiring house wall? Whether a bed was located in an opening in the tiring house wall or put out on stage, the usual assumption is that a wide central opening - a 'discovery space' — was used; but it is far from certain that such an opening existed. The standard idea of an early modern stage bed is a canopied and curtained four-poster, although such a structure would have blocked sightlines and been very cumbersome. More generally, since bed scenes would have entailed extra staging demands, we might ask why playwrights nevertheless wanted to include them. The purpose of this study is to consider these and related matters with reference to all beds in plays written between 1580 and 1642. But because there is much we still do not and probably never will know about early modern playhouse conditions, I cannot claim to have arrived at answers that eliminate the need to rely on shaky assumptions. My hope is that by examining the extant evidence I have been able to offer an informed and useful range of possibilities.

Leslie Thomson (1.thomson@utoronto.ca) is professor emeritus of English at the University of Toronto. 


\section{Kinds and Counts}

The primary reference for discussions of beds in early modern plays is Richard Hosley's 1959 article, 'The Staging of Desdemona's Bed'. ${ }^{1}$ This study is certainly useful; but it is also limited because Hosley derived his evidence only from plays written for the Chamberlain's/King's Men. He therefore considered 'twentythree instances of staging a bed' in 153 plays 'written for Shakespeare's company' between 1595 and 1642, regardless of the playhouse they were 'designed' for. ${ }^{2}$ Based on his understanding of how these beds were staged, Hosley concludes that 'Desdemona's bed was originally presented to the view of the audience not by being discovered but by being brought on stage. ${ }^{3}$ But twenty-three uses of a bed in 153 plays is only fourteen percent and these beds occur in plays written for a single company. When all uses of a bed in all plays written between 1580 and 1642 are considered, however, the number rises and the range of examples is necessarily and usefully wider, but also more complex. In addition, Hosley's summary conveys the impression that beds were typically brought out on stage rather than located in a tiring house wall opening. But partly because of the limited context of his examples he does not discuss instances that suggest a different staging, nor does he describe the physical property used in Othello or in any of the examples in his survey. Similarly, G.E. Reynolds's study of the Red Bull playhouse considers the use of beds, but only in relation to that venue. Like Hosley, Reynolds concludes that beds were typically located out on the stage: 'I do not see that any rigid rule about the bed-scenes is possible nor any single explanation of why beds were thrust out on the front stage. That they were, however, is sure. ${ }^{4}$ A close consideration of all bed scenes partly confirms but also qualifies these conclusions.

In the roughly 485 extant plays written between 1580 and 1642 for performance in London playhouses, about ninety-three call for a bed or, rarely, a couch. ${ }^{5}$ A search in Literature Online for bed confirms that the word occurs often in plays of this period (over 3000 hits), but when a visible bed or couch is required, it is called for in a stage direction - only nine plays (mostly pre-1600) have dialogue references to a bed that is needed but not signalled in a direction. In fourteen plays the property is called for on two separate occasions, and two plays use a bed three times. Bed scenes recur through the period with, for example, thirteen beds in ten plays between 1590 and 1599, and twenty-six in twenty-five plays between 1630 and 1639.

As with signals for other business in early modern plays, the stage directions that describe bed scenes share many of the same terms and phrases - they are 
examples of the common language used by those who wrote the plays and those who staged them. Our problem is that often we do not know exactly what a term or phrase refers to. Nevertheless, the use of similar terminology in similar contexts from play to play allows us to begin the task of interpretation. In this section I provide counts of these commonalities and attempt to interpret them; in the final two sections I consider the actual performance implications.

Most frequent are calls for a bed to be thrust, put, or drawn out on stage (and, rarely, put/drawn off stage); twenty-four of the ninety-three plays include a direction for a bed to be put out and five for a bed to be taken off. ${ }^{6}$ The first play to use the most common version of the phrase is A Chaste Maid in Cheapside (1613; Swan): 'A Bed thrust out vpon the Stage, Allwits Wife in it'. Other examples include 'A bed thrust out, Antoninus vpon it sicke, with Phisitions about him' (The Virgin Martyr, 1620; Red Bull); also 'Put forth a bed, Anthynus on it bound' (The Queen's Exchange, 1631; Blackfriars? Globe?); and 'Syllana drawn out upon a Bed as sleeping, to whom Silius with a light Torch enters' (Messalina, 1634).

Next most common is some version of 'Enter $X$ in bed', found in twenty-one plays. Basic examples include 'Enter Elizabeth in her Bed, Doctor Owine, and Doctor Wendith' (If You Know Not Me You Know Nobody, Part 1, 1604; Red Bull); 'Enter Imogen, in her Bed, and a Lady' (Cymbeline, 1609; Blackfriars); and 'Enter Oriana on a bed' (The Wild Goose Chase, 1621; Blackfriars). ${ }^{8}$ Directions for a figure to enter in or on a bed occur through the period, while those that call for a bed to be moved out onto the stage occur only after 1610 . The first instance of the latter is in The Golden Age (1610; Red Bull), a play in which we also perhaps see the transition from one way to another of directing how a bed is to be put on stage, because the play includes both the earlier format - 'Enter Sibilla lying in childbed, with her child lying by her, and her Nurse, \& c.' — and the later format: 'Enter the foure old Beldams, drawing out Dana's bed: she in it'. Indeed, this play not only provides what is probably the first use of 'draw out' but also its reverse when 'The bed is drawne in'. And a direction in The Silver Age (1611; Red Bull) combines both formulae - 'Enter Semele drawne out in her bed' - strong evidence for the view that enter in bed and drawn out in bed both mean that the property was to be brought out of the tiring house and placed forward on the stage. ${ }^{10}$

Several other plays provide examples of the two formulae used together in ways that confirm their common meaning: a bed was put out on stage. In Four Plays in One (1613), a scene begins 'Enter Violanta in a bed; Angelina and Dorothea sitting by her', which one might think implies a discovery (of a bed and stools), but the scene ends with a dialogue cue: 'Draw in the bed neerer the fire: silken rest, tie all thy cares up.. ${ }^{11}$ In The Spanish Curate (1622; Blackfriars, Court), a dialogue 
cue - 'pray ye bring him out' - followed by 'Enter Diego (in a Bed) Millanes, Arsenio, and Parishioners', is accompanied by 'Bed thrust out'. ${ }^{12}$ In A New Trick to Cheat the Devil (1625), a scene begins 'Enter Anne in Bed, Mistris Changeable, Lord Skales, Treatwell and Geffrey'; it ends with Anne saying 'Hand in my bed' and a direction: 'The Bed pull'd in'. ${ }^{13}$ And The Lost Lady (1637; Blackfriars, Court) includes both 'Enter the Moore on her bed, Hermione, Phillida, and Irene' and 'The bed thrust out', as well as 'Exeunt. Draw in the bed'. ${ }^{14}$ So although Andrew Gurr says that 'a stage direction like "Enter X upon a bed" may mean either that the bed was pushed out onto the stage or that it was discovered', ${ }^{15}$ no evidence supports this view and a number of examples explicitly counter it. Directions for a figure to enter on a bed and for a bed to be drawn out mean that the bed was to be put out on the stage; furthermore, on or upon the stage meant just that: forward onto the stage, not in a recessed location behind the tiring house wall where it could be discovered. ${ }^{16}$ Together, then, directions that call for a bed to be put out on stage or for a figure to enter on a bed account for about fifty of the ninety-three uses of a bed.

In addition, fifteen uses of a bed have neither a signal for a bed to be put out nor a reference to curtains or a discovery but nevertheless almost certainly require a property on stage. Included in this group are the bed used by Henry IV and Volpone's couch as well as the beds on which Edward II is murdered, on which Evadne kills the King, and on which Cleopatra dies and makes her final exit. When these are included the total rises to approximately sixty-five beds that are put out on the stage; this number is almost three-quarters of the beds included in the survey. So Hosley's implicit conclusion that beds were always brought on stage in the King's Men's plays cannot be said of all instances in all plays.

The staging of beds frequently involves the use of curtains (or hangings) although notably only five of the sixty-five scenes in which a bed is definitely put out on stage include a reference to curtains or a discovery. Besides these five, there are twenty-nine bed scenes that refer either to curtains (fifteen) or a discovery effected by opening curtains (thirteen). In all, therefore, thirty-four of the ninety-three uses of a bed include a reference to curtains and/or a discovery. One can seldom be certain, however, if the curtains are on the bed or in front of an opening in the tiring house wall with a bed behind them. Consequently, one can often not be sure where the discovery occurs and whether it is of the bed or of the figure on it; so, the distinction between beds put out on stage and those set in an opening in the tiring house wall is not straightforward.

Before continuing I should explain that I have deliberately not used discovery space because the term — coined by Hosley in the 1950s — refers to a large 
opening in the centre of the tiring house wall, but there is no unqualified evidence that such a fixture existed in all or even any playhouses. Certainly, there are no references specifically to a centre opening in dialogue or stage directions for the staging of beds or otherwise. And to discuss bed scenes based on the assumption that there was a 'discovery space' inevitably removes both staging restrictions and possibilities from consideration. By this rejection of the term, I do not mean that beds were never positioned at an opening in the tiring house wall - the evidence suggests they were - but that one of the two doorways (which we know did exist) would have served the purpose. Tim Fitzpatrick and Wendy Millyard have argued that beds were 'located at one of the two lateral doors' and say that 'We have found no cases in which such an arrangement creates logistical difficulties either for other entrances or for continuity between scenes'. ${ }^{17}$ If Hosley's estimate is correct and the two doors in the Swan drawing are each 'some $7 \mathrm{ft}$. or $8 \mathrm{ft}$. wide', ${ }^{18}$ either of these openings would have been wide enough, even for scenes such as that in Tamburlaine, Part 2 (1588): 'The Arras is drawne, and Zenocrate lies in her Bed of State, Tamburlaine sitting by her: three Phisitians about her bed, tempering potions, Theridamus, Techelles, Vsumcasane, and the three Sons', or in Lust's Dominion (1600): 'The Courtaines being drawn there appears in his bed King Phillip, with his Lords, the princesse Isabella, at the feet Mendoza, Alvero, Hortensio, Fernando, Roderigo, and to them Enter Queen in hast', or in Amends for Ladies (1611; Blackfriars): 'A curtaine drawne, a bed discouer'd Ingen with his sword in his hand, and a Pistoll, the Ladie in a peticoate, the Parson'. ${ }^{19}$

The main reason for believing that such scenes were set up in a recessed space and discovered there is that the directions call for not only an occupied bed but also other properties and several figures, all (seemingly) appearing together in a tableau. The directions for a few other early uses of a bed invite basically the same interpretation. Edward I (1591) has a bed in at least three separate scenes: 'King Edward, Edmund, and Gloster, goes into the Queenes Chamber, the Queenes Tent opens, she is discouered in her bed, attended by Mary Dutchess of Lancaster, Ione of Acon her daughter, \& the Queen dandles his young sonne'; 'Bishop speakes to her in her bed'; 'Elinor in child-bed with her daughter Ione, and other Ladies. ${ }^{20}$ Possibly the 'tent' was a curtain set up in front of an opening in the tiring house wall behind which the bed was located for much of the play, to be revealed when needed. In The First Part of the Contention (1590) three uses of a bed are separated by other action, so either the bed was repeatedly put on and off stage, or it was set where it could be revealed when the plot called for it: 'Then the Curtaines being drawne, Duke Humphrey is discouered in his bed, and two men lying on his brest and smothering him in his bed'; 'Warwicke drawes the curtaines and showes Duke Humphrey 
in his bed'; 'Enter the King and Salsbury, and then the Curtaines be drawne, and the Cardinall is discouered in his bed, and rauing and staring as if he were madde. ${ }^{21}$ For both of these plays, then, practical considerations seem to favour placing the bed in an opening hung with curtains that could be closed when necessary. ${ }^{22}$

The stage directions and contexts for other uses of a bed provide even less certain evidence to support what is at best informed guesswork. But a reference to the discovery of a bed (rather than the figure on it) might be thought more likely to imply that the bed is behind curtains rather than that the actual property is curtained (and forward on the stage). The phrase occurs in Amends for Ladies, in which as already noted multiple elements indicate a bed behind curtains. In addition, All's Lost by Lust (1619) includes 'A bed discovered, on it Lazarello, as Antonio'; The Wonder of a Kingdom (1631; Phoenix?) has 'A Bed discovered, Fyametta upon it'; and the manuscript of The Wasp (1636-9; Salisbury Court?) has 'Bed discouerd. Gilb: in it.' ${ }^{23}$ Several directions use a similar phrasing, but do they signal the same staging? Love's Sacrifice (1632; Phoenix) has 'Enter Biancha, her haire about her eares, in her night mantle; she drawes a Curtaine, where Fernando is discouered in bed, sleeping, she sets downe the Candle before the Bed and goes to the Bed side' and in Love's Mistress (1634; Phoenix, Court) there is 'Cup. discovered, sleeping on a Bed'. ${ }^{24}$ It seems to me that the most one can say is that if there were basically two ways of staging bed scenes — in a recess or out on the stage — these probably fall into the first category.

As I noted above, there are a few scenes with a direction for a figure to enter on a bed and a reference to curtains or a discovery. Given that the most common directions are for a figure to 'enter' on a bed or for a bed to be 'thrust out', it seems probable that in these cases the dominant staging prevailed and a curtained bed was put out on the stage. The True Tragedy of Richard III (1591?) begins 'Enter Edward the fourth, Lord Hastings, Lord Marcus, and Elizabeth. To them Richard' and towards the end of the scene Edward says 'Now draw the Curtaines and depart', which is followed by 'The King dies in his bed'. ${ }^{25}$ If, as this direction seems to indicate, the bed was out on the stage the most straightforward reading is that it was curtained. A similar situation occurs in The Martyred Soldier (1618; Cockpit): 'Enter the King on his bed, two Physitians, Antony, Damianus, and Cosmo' and the king tells the others to 'Draw round the Curtaines'. And in A Trick to Catch the Old One (1605; Paul's, Blackfriars) there is 'Enter Dampit the Vsurer in his bed, Audry spinning by' as he says 'drawe the Curtaine'. ${ }^{26}$ These usages return us to the play that is the focus of Hosley's article - Othello (1604; Globe, Blackfriars, Court, Oxford). In the Folio the direction that begins the last scene is 'Enter 
Othello, and Desdemona in her bed', which I read as a variant of 'Enter X in bed'. Othello's later 'Let me the Curtaines draw' therefore refers to bed curtains. ${ }^{27}$

But as I have also noted, for the considerable majority of bed scenes an uncurtained bed put out on the stage would have sufficed. To these can be added nine plays that call for or refer to a couch, six of which are dated 1626 or later. One of the three earlier instances is in Alphonsus of Germany (1594): 'Enter Alphonso (carried in the Couch)', ${ }^{28}$ but this play was popular later and the extant text, printed in 1654, perhaps reflects later usage. In any case, it indicates that, unlike a bed, a couch could be carried on stage. The Merry Devil of Edmonton (1602; Globe, Court) begins with a Prologue who 'draw[s] the curtains' to reveal the titular character: 'Behold him heere laide on his restlesse couch, / His fatall chime prepared at his head, / His chamber guarded with these sable slights, / And by him stands that Necromanticke chaire. ${ }^{29}$ This seems to be a tableau similar to those I discussed earlier, with the occupied 'couch' and several other properties being discovered. Although only one direction refers to the couch in Volpone (1606; Globe) - 'He leapes off from his couch'30 — it is part of Volpone's disguise as an invalid and was probably put out on stage and used each time he appears in that guise. The direction for Alphonsus to be 'carried in the Couch' in Alphonsus of Germany perhaps indicates that a couch was specified because it was more portable than a bed. Similarly, The Roman Actor (1626; Globe? Blackfriars?) includes 'Enter with couch' and The Wits (1634; Blackfriars, Court) has 'Enter Ample, carried in as sicke in a Couch'. ${ }^{31}$ There are also several plays in which although a bed is referred to, a more portable couch seems to be what is actually called for, as in Antony and Cleopatra (1606-7; Globe) when Caesar directs Cleopatra's final exit: 'Take up her bed'. 32

\section{Property Beds}

What did property beds look like? Did fictional contexts determine their appearance? Did playgoers expect and see real-world beds and of a particular kind, depending on whether the bed was a king's or a poor man's, a young virgin's or a married couple's? How were beds 'dressed'? Whatever its appearance, a bed for two (which many are) would have been a sizeable prop, so how was it handled and managed when in use? Where and how was it stored? How was it put on and taken off stage? The kind of minimal property implied by a 'couch' or a daybed that could be 'taken up' would seem to have been well suited for playhouse use, and possibly such a portable prop was used in more than the few examples just cited. But in many other cases something more substantial seems to have been 
called for by the playwright and required by the dramatic context, therefore raising these aesthetic and practical questions.

On the Henslowe inventory of props transcribed by Edmund Malone, one 'bedsteade' is listed with two tombs and immediately after a rock, cage, tomb, and hell mouth, which leads me to wonder if their being itemized together indicates that as large items they were stored together. ${ }^{33}$ According to the OED a bedstead is 'Strictly, the place occupied by a bed; but long ago transferred to the wooden or metal stand on which a bed is raised; the framework of a bed' (bedstead, $n$.). And the quotations provided by Peter Thornton in his study of early modern furniture make it clear that 'bedstead' was a generic term — usages include 'trunke bedstead', 'settle bedstead', and 'press bedstead'. ${ }^{34}$ Henslowe's reference to a 'bedstead' therefore tells us nothing about what the property looked like, only that there was one. In addition, it is evident from Thornton's detailed consideration of early modern beds that this was a period during which several different styles of bed were in use. That is, the meaning of bedstead might have changed considerably between 1598 when Henslowe's inventory was compiled and the 1620s or '30s when many of the bed scenes in this survey were written.

The oED definition of bed, the more common term and the one used in stage directions (and dialogue), is

A permanent structure or arrangement for sleeping on, or for the sake of rest. In some form or other it constitutes a regular article of household furniture in civilized life, as well as part of the equipment of an army or expedition. It consists for the most part of a sack or mattress of sufficient size, stuffed with something soft or springy, raised generally upon a 'bed-stead' or support, and covered with sheets, blankets, etc., for the purpose of warmth. The name is given both to the whole structure in its most elaborate form, and, as in 'feather-bed,' to the stuffed sack or mattress which constitutes its essential part. 35

This definition too leaves open a wide range of possibilities for what a property bed actually consisted of, but at the very least it seems reasonable to assume that Henslowe's reference to a 'bedstead' and references to a 'bed' in stage directions must have been to a property that could be moved on and off stage without too much difficulty.

Modern critics and editors typically avoid the question of what kind of bed was used by referring simply to 'the bed', a lack of specificity that is understandable but misleading because there is a significant difference between a simple bed and one that included a full tester, ${ }^{36}$ four posts, and curtains. Certainly the latter 
would have created more than a few difficulties both for those handling it and, one supposes, for playgoers trying to see what happened in it; furthermore, some beds clearly needed to be more elaborate than others. In particular, as we have seen, while some stagings of a bed call for curtains many do not, which raises the question of whether a curtained bed was used even when curtains were not required. If the social or cultural plot context meant a certain kind of bed, was an attempt made to produce it? For example, upper and middle class beds in the real world typically had a tester and curtains, and most stage beds are linked to figures belonging to those classes, so was a substantial bed with all the trimmings used regardless of whether or not curtains were required in the scene? On the one hand, we have no way of knowing the answer to this question; but, on the other, that many bed scenes have no reference to curtains makes one wonder if a simpler prop was used when possible, regardless of its appropriateness.

In his article on the use of beds Hosley never specifies what kind of bed he means, although when referring to The Rape of Lucrece he observes cryptically that 'by definition the bed is curtained' 37 and in a discussion of Sophonisba elsewhere he says 'presumably a small, curtained four-poster bed was brought on and off stage in each scene. ${ }^{38}$ Glynne Wickham mentions getting 'a large four-poster bed' 39 off stage, and Andrew Gurr also refers to 'a four-poster bed'; 40 but none of the three critics gives a reason for his supposition. Since no stage direction refers to a four-poster bed, or to bed posts, and only one refers to 'bed curtains', ${ }^{41}$ these critics' assumptions are not only questionable but also problematic in practical terms.

Furniture historians who discuss Elizabethan and Jacobean beds are helpful in describing the kinds of bed that existed; but unfortunately no histories specifically depict stage furniture or consider how a property bed might have differed from a real one for practical reasons. In addition, because they were made of wood, few early modern beds survive, and those that do are typically substantial and essentially unmoveable constructions - the Great Bed of Ware being the most obvious example. Nevertheless, a few contemporary household inventories include beds, giving a sense of the variety of kinds and terms.

In a study of inventories of furniture in a house in northern England - Brownsholme Hall — Simon Jervis provides details from 'inventories ... earlier than the Civil War, comprising two of about 1591, one of 1610 and two of 1634, a remarkable group especially for such a remote house. ${ }^{42}$ He summarizes the kinds of bed referred to in the five inventories (indicated by roman numerals): 
Bed (II), stand bed (I, IV, V), stand testered bed (IV, V), great stand bed with a tester (IV, V), standing bed (I, II, III, V), plain standing bed (II), standing bed with a tester (II), standing bed with wainscot tester (III), bedstead (III, IV, V), bedstocks (III), pair of bedstocks (I, IV, V), pair of plain bedstocks (II), wheel bed (II, V), truckle bed (I, IV, V), pair of truckle bedstocks (I), trundle bed (III), trundle bedstead (III). (3)

Clearly, bed could also mean mattress, as in a 'feather bed' that is placed on a 'standing bed' or a 'chaffe bed' placed on a 'truckle bed'. And in a study of furniture of the period in Oxford, Pauline Agius notes that

'High', 'standing', 'truckle', 'half-headed', 'press' and 'field' bedsteads are all listed frequently. The term Standing Bed was often used to imply one with columns and panelled head and a tester but most of the beds listed are not described and some may well have been of the earlier type of high bed with rudimentary wooden framework fully covered by curtains and hangings though some, ... were 'without testornes' ${ }^{43}$

A standing bed was 'a high bedstead, as distinguished from a truckle-bed'. 44 Standing beds could be elaborate pieces of furniture, consisting of a frame with posts, tester, and curtains, within which was the sleeping platform consisting of a wooden frame with multiple layers of mattresses and blankets. The truckle bed and field bed were smaller and more transportable, and might have made useful stage beds, although they had particular functions and associations in the real world not in keeping with the contexts for the use of at least some of the beds required in the theatre. ${ }^{45}$

Peter Thornton's descriptions of early modern canopied and curtained fourposter beds make it clear that they were indeed substantial and he says that it was presumably not intended that any of these beds were to be moved in the ordinary course of events. 46 He also notes that

Scholars have often been misled by the term 'canopy bed' which occurs frequently in inventories from the first half of the [seventeenth] century. The 'canopy' was suspended over the head of the bed ... by means of a cord attached to the ceiling ... It usually consisted of a cone-shaped or domed 'bowl' with a valance all round and with two or three large curtains that were often called 'trains' because they had to drag ... on the ground, in order to be long enough to reach out and also encompass the foot-end of the bed. The French called such canopies pavillions. ${ }^{47}$ 
Since numerous directions refer to curtains and a few to a canopy, perhaps rather than being suspended from the ceiling an overhead fixture could have been attached to a stage bed — although admittedly this attachment would have made it more cumbersome to move on and off stage. And if the aim was staging practicality rather than real-world authenticity, there were possibilities other than a multi-part four-poster. The curtain arrangement Thornton describes here seems to be very like the 'half-tester' bed, so called because the tester 'only covered the head-half of the bed.' In the real world 'such beds were used by persons of secondary status', ${ }^{48}$ but on the stage a half-tester bed might have been a much more practical prop than a bed with a full tester supported by four posts and with curtains on all sides.

As to what couch referred to, the OED indicates how little difference there was between a bed and a couch, defined as 'A frame or structure, with what is spread over it (or simply a layer of some soft substance), on which to lie down for rest or sleep; a bed'; 'An article of furniture for reclining or sitting on; a lounge (from 1450)'. ${ }^{49}$ And in Henry Cockerham's 1623 Dictionary a couch is simply 'a little bed', ${ }^{50}$ possibly what was referred to as a daybed: 'Originally: a bed used during the day $(o b s$.$) . In later use: a couch or similar piece of furniture used for daytime$ rest or sleep. 51

\section{Beds in Performance - Practical}

How literally should we take stage directions in early modern play-texts? Do staging signals reflect the playwrights' knowledge of what was doable? Or did they mostly write stage directions describing actions and props as they imagined them, regardless of whether they thought or hoped they could be implemented? In particular, how should we understand stage directions for the use of beds? They indicate that the playwright wanted a bed, but did he consider the practicalities of how the bed would be staged? Did he think about whether curtains would be hung at a doorway or on the bed? And even if he did consider these matters, does that mean his stage direction was or could be implemented as written? In some cases at least, stage directions can certainly give us information about the possibilities and restrictions of early modern performance spaces; but more often they are incomplete, contradictory, inadequate, unclear, and possibly also idealized and not stageable. So although stage directions are almost all the evidence we have, we need some scepticism to avoid being misled into accepting as fact what might be a playwright's fantasy. 
Fortunately, we have some rare evidence for how beds were treated in the playhouse. A few play-texts with bed scenes include annotations made by a bookkeeper when readying a play for performance. Best known perhaps is the manuscript of the play usually referred to as Thomas of Woodstock (1592), which includes the note ' $A$ bed for woodstock'. ${ }^{52}$ This direction has been variously interpreted, but there is general agreement that it was written by the man preparing the play for the stage. ${ }^{53}$ In the Sir John van Olden Barnavelt (1619; Globe) manuscript, a bookkeeper has added 'Son abed', ${ }^{5}$ which if nothing else (the staging is difficult to decipher) is an interpolated direction for what the text only implies. The practical purpose of such annotations is much clearer in The Spanish Curate, a printed text that includes what are almost certainly a bookkeeper's additions to the underlying manuscript. First 'Bed ready, wine, table Standish \& Paper' is placed ahead of the actual stage direction; then comes 'Diego ready in bed, wine, cup' before the direction for him to appear. When this comes — 'Enter Diego (in a Bed)' - it is accompanied by the bookkeeper's 'Bed thrust out'. ${ }^{5}$ Similarly, in the manuscript of The Wasp the bookkeeper has added three notes: 'Bed readye' and 'Bed Gilbert' in the left margin and at the dialogue signal 'vncurten come lets se him', 'Bed discouerd. Gilb: in it ${ }^{56}$

Another kind of evidence for the actual treatment of beds occurs in a few plays that exist in two versions, one with a bed the other without. The Battle of Alcazar (1589) raises many complex textual and performance questions that cannot be addressed here; but at the most basic level, the quarto twice calls for a bed that is not mentioned in the theatrical plot. ${ }^{57}$ The First Part of the Contention (1591-2) includes 'Duke Humphrey is discouered in his bed, and two men lying on his brest and smothering him in his bed' but the murder in the bed is not shown in the Folio version, Henry VI, Part 2. Conversely, whereas the quarto has 'Warwicke drawes the curtaines and showes Duke Humphrey in his bed,' the Folio has 'Bed put forth'. ${ }^{58}$ Perhaps these differences were necessitated by practical considerations, perhaps not; either way they are evidence that business with a bed could change. ${ }^{59}$ Probably the clearest example of a bed being excised is in the manuscript version of The Woman's Prize, or The Tamer Tamed (1611; Blackfriars? Court). The version in the 1647 Beaumont and Fletcher Folio includes 'Enter Livia discovered abed, and Moroso by her' which in the manuscript is 'Enter Liuia sick carryed in a chaire by seruants; Moroso by her'. Furthermore, when the bed is used in the Folio version, one figure refers to curtains, saying 'draw 'em softly', which in the manuscript becomes 'bear her softly'; 'lie' in the Folio becomes 'sit' in the manuscript and at the end of the scene the Folio's 'draw all the Curtaines close' has been omitted in the manuscript leaving a gap in the dialogue. ${ }^{60}$ One explanation for eliminating a 
bed is that the physical conditions of the venue permitted the use of the prop for the Folio version but not for the manuscript version; but also possible is that the bed was eliminated simply because it took more time to stage. (The evidence suggests that the manuscript version was shortened for performance. ${ }^{61}$ In Aglaura (1637; Cockpit, Court) there are two versions of act 5, one without a bed and one with 'A bed put out: Thersames and Aglaura on it, Andrages by' followed soon after by 'Draw in the bed'. ${ }^{62}$

In addition to these examples there is the annotated quarto of The Two Merry Milkmaids (1619; Red Bull, Court), a substantial fragment, prepared by at least two bookkeepers for two different productions. ${ }^{63}$ At the beginning of 4.1, one bookkeeper wrote 'Ready Bed', but the bed is not used until 4.3. Just before the end of 4.1, thirteen pages after the first cue, the same bookkeeper wrote 'Bed Ready' in the margin not long before the quarto's 'A Bed thrust out, Enter Lady the old Lord, some other Lady and Aliens. ${ }^{64}$ Possibly the bed was to be made 'ready' behind the tiring house wall and pushed forward when needed. On the one hand, this evidence suggests that the bed had to be brought into readiness between acts, at least for the production prepared by this bookkeeper (designated B). On the other hand, one wonders how the actors would have manoeuvred around the bed if it were brought into the space behind the tiring house wall so long before it was required. Perhaps, however, the earlier notation was put there by $\mathrm{B}$ as a reminder to himself that the bed would have to be brought forward later (as possibly in Woodstock). But that is not the whole story evident on these pages: just below B's second call for the bed to be ready is a long deletion by the other bookkeeper (A), which removes the bed altogether. ${ }^{65}$

As the changes just itemized suggest, bed scenes could be and doubtless were adjusted or deleted to suit the performance context. And many of the ninety-plus plays that include a bed were performed in more than one venue over time. This fact raises the question of whether playwrights wrote with a particular playing space in mind or if they expected adjustments to be made depending on the venue. Most obviously, many outdoor playhouses, such as the Globe, Red Bull, and Fortune, had large and deep stages whereas the indoor Blackfriars, Cockpit/Phoenix, and Salisbury Court theatres had smaller, shallower stages. And we know from the Rose excavations that in both iterations its stage was wider than it was deep. ${ }^{66}$ With such a configuration, one surmises, locating a bed in an opening in the tiring house wall would have been more workable than on a deeper stage with a greater distance between playgoers and action far upstage. Moreover, twenty of the plays with beds (including Othello and The Rape of Lucrece) were performed at Court, where different conditions surely required adjustments. 
But the repeated use of similar phrasing in stage directions through the period indicates that conventions governed the staging of beds. And a repertory system characterized by a revolving schedule of plays, different venues, and minimal rehearsal could not have functioned effectively unless common staging practices — for beds and much else — were employed most of the time. The evidence of the stage directions set out in the first section of this study leads me to several working premises about these staging conventions: 1) enter meant to come out of an opening in the tiring house wall onto the stage; 2) by far the most common directions for a bed are those for the bed and the figure on it to 'enter' or for an occupied bed to be 'thrust out'; therefore, 3) when a direction is ambiguous but seems to signal that the bed was or could have been put out on stage, in practice it probably was. Some beds were located in or at an opening in the tiring house wall, to be sure, but everything suggests that this staging would have been less effective both practically and theatrically. ${ }^{67}$

But did the many beds that were put out on stage have curtains by default? That is, was the basic property a curtained bed regardless of whether or not the curtains were called for in a particular instance? On the one hand, as I indicated in the previous section, a bed with curtains would have entailed a tester or frame from which to hang them and therefore have been a large and cumbersome prop. In addition, these fixtures above and around the bed would surely have blocked sightlines. On the other hand, real beds of the middle and upper classes were typically curtained, and as contemporary illustrations show, bed curtains could be tied up when not in use. ${ }^{68}$ That only a few plays unequivocally and explicitly require an onstage bed with curtains might therefore be evidence that such a prop was rarely needed; conversely, these few examples might be evidence of a practice that generally went unspecified because it was conventional. ${ }^{69}$ Either way, these scenes warrant consideration. In The Golden Age a bed scene begins 'Enter the foure old Beldams, drawing out Dana's bed: she in it' then Jupiter 'lyes vpon her bed' and she says 'If you will needs, for modesties chast law, / Before you come to bed, the curtains draw', after which 'The bed is drawne in'. ${ }^{70}$ The Atheist's Tragedy (1611) has 'A Bed drawne forth with Rousard' coupled with a dialogue direction to 'withdraw the Curtaines'. A Mad Couple Well Matched (1639) has a 'Bed put forth, Alicia in it' and when a figure gets into bed with her she tells him 'you may draw the Curtaines, and sleepe by me' 71 These examples return us to the bed scene in Othello because it is almost certainly staged the same way: as Hosley concluded, a bed with Desdemona on it is put out on stage; after Othello has strangled her and Emilia calls to him he closes the bed curtains; Emilia enters and opens the curtains to reveal her dying mistress. 
Also to be considered is how a bed was positioned once on stage: side-on or foot-forward. In a 1995 unpublished paper John Astington offered a cogently argued suggestion and rationale, to which I cannot do justice, but from which I shall quote extensively. ${ }^{72}$ Astington provides a number of non-theatrical images, noting that "The consistent graphic paradigm in these illustrations is that the bed is represented laterally — side on to the observer's view - allowing figures to be grouped around it in various visual relationships'. He asks 'How might iconographic convention have influenced stage practice, if at all? Did the dominance of the lateral alignment and grouping in graphic representation determine or influence the way in which actors gave bed scenes physical embodiment on stage? Would audiences have expected to see on stage what they were used to seeing in paintings, prints, and graphic decoration?'. And he notes that 'Even the very largest Elizabethan platforms - the Red Lion, at 30' x 40', and the Fortune, at $27^{\prime} \times 43^{\prime}$ - were wider than they were deep and, if the stage pillars actually did create a "forestage" as the Swan drawing suggests, then on such an area width was far greater than depth, and lateral composition would have been the natural consequence'. Astington concludes: 'The side-on arrangement opens the bed and its occupants to as full a view as possible, makes the most of the bed itself as an object of visual attention, and creates a spatial field around, behind, and in front of it'. Whether or not playwrights and players sought to reproduce on stage the bed scenes in contemporary illustrations, the possibilities for effective staging would have been enhanced if stage beds were put out sideways.

When we turn to those beds that seem to have been staged behind the tiring house wall and revealed by drawing curtains that hung over an opening in that wall, the matter of whether the bed was foot-forward or side-on seems even more pertinent. If the former, it would have been difficult for many playgoers to see the occupant of the bed; if the latter, a very wide opening would have been needed to accommodate both a bed and those around it. But perhaps even those bed scenes that began behind the tiring house wall moved out onto the stage after the curtains had parted. If this was how such scenes were managed, not only would the bed have been more visible, it would also not have been in the way backstage. ${ }^{73} \mathrm{~A}$ bed scene in Monsieur Thomas (1615; Blackfriars) begins 'a bed discovered with a black More in it' and ends 'Draw in the bed Maides', directions that together can be interpreted to mean that the bed was revealed in an opening in the tiring house wall and then moved forward onto the stage for the long ensuing scene which involves continuous reference to and activity on and around the bed. ${ }^{74}$

Uncertainties about the location and orientation of property beds prompt further questions, including about how far out on the stage they were put. Common 
sense suggests that a bed would have been positioned far enough forward to be visible (or why bother). But the players would presumably also have wanted to minimize the difficulty of moving a sizeable and (usually) occupied property onstage and then off again when it was no longer needed. There must have been a reasonably efficient method, and although there are no indications in play-texts, it seems likely that there would have been a pause in the action while a bed was dealt with. Indeed, beds are often introduced at the start of a scene, when there is a cleared stage and a natural pause. And since one function of a bed is to signal that the location is a bedchamber and typically a bed scene is followed by action in a different place, the property would almost certainly have been either hidden (by a curtain) or removed as the scene ended. Nevertheless, of all the plays calling for a figure to enter in bed or for a bed to be put out on stage only seven include a corresponding signal for the property to be taken off - five stage directions and two dialogue cues. The Golden Age again provides an example, this time of the first such direction: 'The bed is drawne in'; 75 but nothing indicates who is to perform the task. In A New Trick to Cheat the Devil, however, the bed scene concludes with the figure on the bed saying 'Hand in my bed' followed by 'The Bed pull'd in' ${ }^{76}$ which suggest that those she addresses on stage take her and the bed with them when they exit. This action is made even more explicit in The City Wit (1630; Salisbury Court): 'They put in the Bed, and withdraw all. Exeunt'. ${ }^{77}$ As I noted previously, Caesar directs others to 'Take up her bed' in Antony and Cleopatra and a bed scene in Four Plays in One concludes with 'Draw in the bed neerer the fire'. ${ }^{78}$ That more playwrights did not supply such signals probably means they and the players knew that as a rule a bed would be removed when the action on and around it ended. ${ }^{79}$ Evidence for what happens at the end of a bed scene that seems to have been set in an opening in the tiring house wall is even sparser. Indeed, the only clear instance is in Tamburlaine, Part 2 where the bed scene concludes with 'The Arras is drawne', echoing the same direction at the start of the scene for the reverse action when the bed is revealed. ${ }^{80}$

Lily B. Campbell concluded that the theatres were equipped with a wheeled platform for putting out large properties because such a device was used in the Greek and Roman theatres, about which much was known and written in the Renaissance. ${ }^{81}$ But the paucity of actual evidence for the use of wheeled platforms in the playhouses of early modern London appears to have kept most other theatre historians from accepting Campbell's argument, although G.E. Reynolds cites it as a possibility ${ }^{82}$ and it has found a place in at least two other studies. ${ }^{83}$ While this option is an appealing solution to what must have been a real problem, with no contemporary verbal or visual support it must remain in the realm of fanciful 
speculation. The only kind of early modern real-world bed with wheels was the small 'trundle bed' that was stored under a 'standing bed' and used by servants, which makes it unlikely that this was the 'bed' referred to in stage directions and dialogue. ${ }^{84}$

Another question worth asking is if a company or playhouse bed was convertible into other large props, because it seems improbable that both a bed and a banquet table, for example, could have been stored in the tiring house when not in use, or that two such properties could have been deployed in the same play, especially in close succession as occurs in 'Tis Pity She's a Whore (1632; Phoenix) where the bed scene in 5.5 is followed immediately by a banquet in 5.6.

\section{Beds in Performance - Thematic and Symbolic}

The use of stage beds must have been a deliberate choice by playwrights, because there were alternatives: there are stage directions for figures to enter 'as from bed' or 'as though to bed', and/or wearing a nightgown or nightcap. ${ }^{85}$ In other plays a figure appears (sometimes in nightclothes) on the upper level, which the dialogue designates as his or her chamber window. ${ }^{86}$ But playwrights call for a bed in almost 100 plays and, presumably, considered it necessary despite all the practical problems just surveyed. Why?

Beds are used in a number of predictable contexts. Most commonly, the figure on a bed is either ill or dying, and sometimes the occupant is murdered. Much less often, beds are places of restraint or seclusion. If a bed is linked to sleeping, however, it is typically only as the scene begins (as in Othello) - the sleeping Innogen in Cymbeline 2.2 is a noteworthy exception for a plot-based reason. Usually figures sleep in chairs or on the stage (described as the 'ground' or a 'bank'); beds are the setting for action on or around them, not for sleeping. Beds are sometimes used to stage the lead up to or consequences of sexual activity but (unsurprisingly) not for the act itself. A partial and contradictory exception is the bed-trick, because although typically this plot convention does not require a visible bed, ${ }^{87}$ in three instances (discussed below) the bed is central to the scene. Although many of the best known theatrical beds have a female occupant, overall about fifty bed scenes have a male figure in the bed and about forty have a female; in five instances the bed is empty, and in five it is occupied by a couple. More generally and regardless of the particular context or gender, a figure on a bed is usually somehow vulnerable and rarely has control over her or his situation. Hence bed scenes often include an element of titillation and voyeurism as part of their effect. In other cases a curtained bed creates suspense and anticipation of a discovery. ${ }^{88}$ 
Like other props, beds have thematic and strategic functions. In 3.5 of Romeo and Juliet (1596) the new husband and wife appear above at what we are to imagine is Juliet's window; the marriage bed is not shown. But the prop is used in 4.3 when, as the Q1 stage direction tells us, after drinking the potion Juliet 'fals upon her bed within the Curtaines' where the Nurse later reveals her. ${ }^{89}$ Similarly, in 'Tis Pity She's a Whore there is no bed for the consummation scene: the incestuous couple appear 'as from their Chamber'. But 5.5 begins 'Enter Giovanni and Annabella lying on a bed', where he murders her. ${ }^{90}$ And $A$ Woman Killed with Kindness (1603) does not show Frankford actually finding Wendoll and Anne together in bed; instead the playgoer sees 'Wendol running ouer the stage in a night-gowne' and 'Mistris Frankeford in her smocke, night-gowne, and night attyre'. But in the last scene, when Anne is about to die of penitent self-starvation, she enters 'in her bed' where she stays until the play's end. ${ }^{11}$ In each of these instances the decision to use a bed or not seems to have depended on reasons that had nothing to do with practicality. Indeed, as in these cases where a bed appears not for the consummation but to dramatize the consequences of that unseen event, thematic and symbolic reasons seem to have determined both when a bed would be required and how it would be used.

In Marston's Sophonisba (1605; Blackfriars) a bed features in a thematically linked sequence of three discoveries. First, 'The Ladies lay the Princes in a faire bed, and close the curtaines whilst Massinissa Enters'. The bride and groom are about to consummate their marriage. Then 'Enter ... Massinissa in his night gowne, led by Asdrubal and Hanno ... the boyes draw the curtaines, discouering Sophonisba, to whom Massinissa speaks. ${ }^{92}$ At the end of this scene and of act 1, 'The Ladies draw the curtaines about Sophonisba, the rest accompany Massinissa forth', phrasing that suggests curtains on the bed. This discovery of the bride on her wedding night will then contrast with two subsequent discoveries. In act 3 Massinissa's rival for Sophonisba is about to come to bed. She and her maid drug her guard, Vangue, and 'They lay Vangue in Syphax bed \& draw the curtaines'. Sophonisba and her maid escape before Syphax enters and 'Offering to leape into bed, he discouers Vangue', then kills him on the bed. The prop is not needed again until 4.1 when the enchantress Erictho enters 'in the shape of Sophonisba, her face vailed, and hasteth in the bed of Syphax'. The next direction is 'Syphax hasteneth within the Canopy as to Sophonisbas bed', setting up a bed-trick. ${ }^{93}$ This action ends act 4 and when act 5 begins the implication is that Syphax thinks he has had sex with Sophonisba until he 'drawes the curtaines and discouers Erichtho lying with him' on the bed. ${ }^{94}$

The Maid's Tragedy (1610; Blackfriars, Court) includes one of the most distinctive and memorable bed scenes of the period. It begins with the direction ' $K$. 
a bed' when Evadne reveals the King, probably by opening bed curtains. She then 'Ties his armes to the bed' 95 and during a long episode stabs him to death. Clearly rather than love-making the playwrights wanted to stage 'death-making' and they had reason to expect playgoers would be able to see it. But this bed was probably equipped with posts to which the king is tied, and therefore perhaps also a tester or frame from which curtains were suspended, both of which would have blocked sightlines for at least some playgoers. ${ }^{96}$ Also significant, therefore, is how effectively the dialogue describes the action - which is also a feature of other similar scenes, such as that in Othello.

The thematic and symbolic benefits of using a property bed seem to have made it worth the practical challenges. Not surprisingly, the use of a bed is typically pivotal in a play's plot - a visual event with a significant build up and consequential effect. Indeed, in The Rape of Lucrece (1607; Red Bull, Court, Phoenix, Oxford) playgoers would have expected the event when they heard the title and Heywood does not disappoint. The sequence begins with 'Lucr. discouerd in her bed' by Tarquin, who exclaims 'Heere, heere, behold! beneath these Curtaines lyes / That bright enchantresse that hath daz'd my eies'. The voyeuristic and titillating possibilities of beds are effectively exploited here as he describes the sleeping Lucrece. And after she awakens his words indicate that he tries to get into bed with her; when she resists he says, 'These cushens first shall stop thy breath, / If thou but shreekest harke how ile frame thy death', from which we learn that the property is a substantial bed with curtains and pillows. And it has served its purpose: the murder of a vulnerable woman on a bed - as in Othello - is permissible, but a rape is not, and the scene ends with 'He beares her out'. ${ }^{97}$

The Traitor (1631; Cockpit) includes a long final scene in which the bed is central to the action on and around it, suggesting that it should have been visible to most playgoers. It begins with 'Amidea discoverd in a Bed, prepar'd by two Gentlewomen'. She is dead but her lover the Duke thinks she is alive during a long scene in which he talks to, touches, and then 'Kisses' the body, at which point he realizes the truth. He is stabbed and his dead body is put on the bed with hers. Then the Duke's murderer, Lorenzo, says 'hide their faces' and briefly pretends to Sciarrha that the two on the bed are alive before showing him that both are dead. They repeatedly refer and gesture to the bed, which is still on stage at the end of the play when it serves as an emblem for this moralizing motto: 'Tis a sad night my Lords, by these you see / There is no stay in proud mortality'. ${ }^{98}$

As I have noted, bed-tricks usually happen off stage and no bed is required. But besides the scene in Sophonisba, in which the bed is the centre of the action and only the actual 'consummation' occurs off stage (between acts 4 and 5), two 
other bed-tricks also give the bed prominence. All's Lost by Lust (1619, Phoenix) has what seems to be a doubly ironic use of the convention because instead of one female substituting for another, here a male replaces another male; and the result is not lovemaking but murder. Both ironies are displayed in the scene's initial action: 'A bed discovered, on it Lazarello, as Antonio: Enter Margaretta and Fydella with a halter. 99 This direction does not indicate where or how the bed was 'discovered'; but given the importance of the action very likely a curtained bed was out on the stage rather than in an opening in the tiring house wall. Here again, as the women strangle Lazarello thinking he is Antonio, they provide a helpful description of what they are doing and how he is behaving.

Perhaps the bed-trick in Heywood's A Maidenhead Well Lost (1639; Phoenix) could only have been written and staged late in the history of the convention, because it is (to my knowledge) unique in having the bed visible throughout the episode. Maybe for this reason it is also the only bed included in a dumb show, which begins 'A Dumbe Shew. Enter Millaine, to him Stroza, and bring in Lauretta masked, the Duke takes her and puts her into the Bed, and Exit'. The masked Lauretta, a wedding night substitute for Julia, is joined in bed by the new husband: 'Enter againe with the Prince to bring him to bed: They cheere him on, and others snatch his Pointes, and so Exit' and the act ends. Then comes a further twist when the Prince, ignorant that she was his partner the previous night, comes to visit Lauretta, who is 'drawne out vpon a Bed'. ${ }^{100}$ In the fiction this is a different bed, but in reality it was surely the same prop as before, with different bedclothes. The bed is visible (perhaps Lauretta remains on it) through a long exchange between her and the Prince in which her double entendres remind playgoers of what she knows but he does not, until finally she tells him the truth. There is no apparent reason for including the prop in this scene except for the ironies it emphasizes visually.

Coming at the end of the period as it does, A Maidenhead Well Lost invites some concluding observations about bed scenes. Heywood was an experienced playwright who first used a bed in 1604 in If You Know Not Me You Know Nobody and was still doing so three decades later. ${ }^{101}$ This usage seems a good indication that bed scenes continued to be popular dramatic devices. Furthermore, that $A$ Maidenhead Well Lost includes two uses of a property bed furthers the impression that it was worth the trouble. More particularly, the stage directions for these two bed scenes are essentially no different from earlier directions, strong evidence that they conveyed the necessary information to the players and playhouse personnel who put them into action. If over the sixty years signals had become more specific about such matters as where a bed was located, how it was brought on stage, what 
it looked like, and how it was taken off, the directions would be much easier for us to interpret; but that they did not change tells us they made sense then.

\section{Notes}

1 Richard Hosley, 'The Staging of Desdemona's Bed', Shakespeare Quarterly 14 (1963), 57-65, http://dx.doi.org/10.2307/2868138.

2 Ibid, 60.

3 Ibid, 57. This is essentially also Chambers's conclusion, although Hosley does not cite him. See E.K. Chambers, The Elizabethan Stage, (Oxford, 1923), 3.112.

4 G.E. Reynolds, The Staging of Elizabethan Plays at the Red Bull Theater, 1605-1625 (New York, 1940), 69. See also C. Walter Hodges, Enter the Whole Army (Cambridge, 1999), although the chapter 'Stage Beds and Other Furniture' deals only with several Shakespeare plays.

5 I actually found ninety-eight plays with bed scenes, but I have excluded five that probably tell us little about the relevant staging practices; these are Sappho and Phao (probably written for performance at court), Tom a Lincoln (probably written for Inns of Court performance), The Strange Discovery (probably never performed), Landgartha (performed in Ireland), and The Parson's Wedding. Hosley omitted the latter 'on the assumption that the printed text (F 1663) was designed for production in a Restoration playhouse' ('Staging', 64, n 19).

6 Unlike other large properties (scaffold, banquet, table, chairs, bier/coffin/hearse, bar) beds are never 'set out'. Only beds are 'put out', and with one exception (a scaffold in The Virgin Martyr, I3r) only beds are 'thrust out'.

7 At the first reference to a play in the essay I give the probable date of composition and/or first performance and, when reasonably certain, the playhouse. In the notes I give the date of publication. For all plays cited, the place of publication is London. In quoting stage directions I use italic regardless of how they appear in the original text, but have retained the original spelling and punctuation. In some cases I quote only the relevant part of a longer direction. Thomas Middleton, $A$ Chaste Maid in Cheapside (1613; sTC: 17877), E4r; Thomas Dekker and Philip Massinger, The Virgin Martyr (1620; sTC: 17644a), H2v; Richard Brome, The Queen's Exchange (1657; Wing: B4882), E4v; Nathaniel Richards, Messalina (1640; sTc: 21011), C7v.

8 Thomas Heywood, If You Know Not Me You Know Nobody, Part 1 (1605; sтc: 13328), B2r; William Shakespeare, Cymbeline (1623; sтC: 22273), zz6v; John Fletcher, The Wild Goose Chase (1652; Wing: B1616), M4v.

9 Thomas Heywood, The Golden Age (1610; sтc: 13325), C2r, I1v, I2v. 
10 Thomas Heywood, The Silver Age (1613; sTC: 13365), I4v. The only uses of 'enter in' that might indicate staging in a tiring house wall opening are for study and shop scenes, but the direction could mean that the relevant props were put out on stage before the scene began. In addition, unlike shops and studies, beds (like sick-chairs) are properties, put out on stage with a figure on them.

11 John Fletcher, Four Plays, or Moral Representations, in One (1647; Wing: B1581), $8 \mathrm{E} 2 \mathrm{r}, 8 \mathrm{E} 2 \mathrm{v}$.

12 John Fletcher and Philip Massinger, The Spanish Curate (1647; Wing: B1581), F4v, G1r, G1v.

13 Robert Davenport, A New Trick to Cheat the Devil (1639; sTC: 6315), I4r, I4v.

14 William Berkeley, The Lost Lady (1638; stc: 1901.5), L2r, M2r.

15 Andrew Gurr, The Shakespearean Stage, fourth edition (Cambridge, 2009), 188.

16 There is no instance in any stage direction of this period where 'the stage' refers to anything other than the main platform in front of the rear wall.

17 Tim Fitzpatrick and Wendy Millyard, 'Hangings, Doors and Discoveries: Conflicting Evidence or Problematic Assumptions?' Theatre Notebook 54 (2000), 10.

18 Richard Hosley, 'The Discovery-Space in Shakespeare's Globe', Shakespeare Survey 12 (1959), 41, http://dx.doi.org/10.1017/ccol0521064252.005.

19 Christopher Marlowe, Tamburlaine, Part 2 (1590; sтc: 17425), C6r; Anon., Lust's Dominion (1657; Wing: L3504A), B6v; Nathan Field, Amends for Ladies (1618; sTC: 10851), H3r.

20 George Peele, Edward I (1593; stc: 19535), F4r, H4r, K3v.

21 William Shakespeare, The First Part of the Contention (1594; sTC: 26099), E2r, E3r, F1v.

22 According to Claire Saunders, "Dead in His Bed": Shakespeare's Staging of the Death of the Duke of Gloucester in 2 Henry VI', Review of English Studies, ns 36 (1985), 19-34, http://dx.doi.org/10.1093/res/xxxvi.141.19, 'Such matters of staging as whether the bed is recessed or thrust forth and how it is concealed or removed are technical matters, of secondary importance' (34).

23 William Rowley, All's Lost by Lust (1633; sтc: 21425), G4v. Thomas Dekker, The Wonder of a Kingdom (1636; sтc: 6533), E2r. Anon., The Wasp, ed. J.W. Lever (Oxford, 1976), 1. 62.

24 John Ford, Love's Sacrifice (1633; stc: 11164), F1v; Thomas Heywood, Love's Mistress (1636; sTC: 13352), F2r.

25 Anon, The True Tragedy of Richard III (1594; sтC: 21009), A4r, B1v.

26 Henry Shirley, The Martyred Soldier (1638; sтc: 22435), F1v, F2r; Thomas Middleton, A Trick to Catch the Old One (1608; stc: 17896), G3r.

27 William Shakespeare, Othello (1623; sтc: 22273), vv4r, vv4v. 
28 Anon., Alphonsus of Germany (1654; Wing: C1952), H1r.

29 Anon., The Merry Devil of Edmonton (1608; sтc: 7493), A3v.

30 Ben Jonson, Volpone (1616; sтc: 14751), Ss4r.

31 Philip Massinger, The Roman Actor (1629; stc: 17642), I4v; William Davenant, The Wits (1636; sтс: 6309), G2r.

32 William Shakespeare, Antony and Cleopatra (1623; sTC: 22273), zz2v.

33 Henslowe's Diary, ed. R.A. Foakes and R.T. Rickert (Cambridge, 1961), 239, 1. 57.

34 Peter Thornton, Seventeenth-Century Interior Decoration in England, France and Holland (New Haven and London, 1978), 169.

35 Oxford English Dictionary Online (oed), bed, n. 1.a.

36 oed, tester, $n$. 1. 'A canopy over a bed, supported on the posts of the bedstead or suspended from the ceiling; formerly (esp. in phrase "tester and celure"), the vertical part at the head of the bed which ascends to and sometimes supports the canopy, or (as some think) the wooden or metal framework supporting the canopy and curtains'.

37 Hosley, 'Staging', 60, n 14.

38 Richard Hosley, The Revels History of Drama in English, vol. 3, 1576-1613, eds J. Leeds Barroll, Alexander Leggatt, Richard Hosley and Alvin Kernan (London, 1975), 219.

39 Glynne Wickham, Early English Stages, vol. 2, pt II (London and New York, 1972), 199.

40 Gurr, The Shakespearean Stage, 189.

41 Thomas Heywood, The Iron Age, Part 2 (1632; sTC: 13340): 'Enter Egistus with his sword drawne, hideth himselfe in the chamber behind the Bed-curtaines' (H3v). No other direction uses even similar phrasing, which only adds to our ignorance of what Heywood had in mind.

42 Simon Jervis, 'Five Early Inventories of Browsholme Hall', Furniture History 22 (1986), 1.

43 Pauline Agius, 'Late Sixteenth- and Seventeenth-Century Furniture in Oxford', Furniture History 7 (1971), 79.

44 OED, standing, adj. 5.b.

45 See in particular the quite elaborate late sixteenth-century field bed illustrated in Thornton, Seventeenth-Century Interior Decoration, Plate 122.

46 Ibid, 157.

47 Ibid, 159, and see the sketches on this page.

48 Ibid, 166.

49 Oed, couch, n. 1.a. and 3.a. See the illustrations in Thornton, Seventeenth-Century Interior Decoration, 173, 174. 
50 Henry Cockeram, The English dictionarie; or, An interpreter of hard English words (London, 1623; sTC 5461.2), C8v.

51 OED, daybed, $n$.

52 Anon., The First Part of the Reign of King Richard the Second, or Thomas of Woodstock, ed. W.P. Frijlink (Oxford, 1929), 11. 2377-8.

53 See William B. Long, “'A bed / for woodstock”: A Warning for the Unwary', Medieval and Renaissance Drama in England, vol. 2 (1985), 91-118, and Gabriel Egan, 'Precision, Consistency and Completeness in Early-Modern Playbook Manuscripts: The Evidence from Thomas of Woodstock and John a Kent and John a Cumber', The Library 12 (2011), 376-91, http://dx.doi.org/10.1093/library/12.4.376.

54 John Fletcher and Philip Massinger, Sir John van Olden Barnavelt (Oxford, 1979), 1. 1656.

55 The Spanish Curate, F4v, G1r, G1v.

56 The Wasp, 11. 41, 51-2, 62.

57 George Peele, The Battle of Alcazar (1594; sтc: 19531), A2v.

58 First Part of the Contention, E2r, E3r; William Shakespeare Henry VI, Part 2, (1623; STC: 22273), n3v.

59 See Saunders, 'Dead in His Bed', passim and Hodges, Enter the Whole Army, 105-6.

60 John Fletcher, The Woman's Prize, or the Tamer Tamed (1647; Wing B1581), 5P4r, 5P4v; The Woman's Prize, ed. Meg Powers Livingston (Oxford, 2008), fol. 45b, 47a, 47b.

61 See The Woman's Prize, ed. Meg Powers Livingston, xix.

62 Sir John Suckling, Aglaura (1638; stc: 23420), N1v.

63 For a detailed analysis, including illustrations of the relevant pages, see Leslie Thomson, 'A Quarto “Marked for Performance”: Evidence of What?', Medieval and Renaissance Drama in England, vol. 8 (1996), 176-210.

64 See K3r, M1v, M2v of the annotated quarto.

65 In fact, despite this preparation by $B$, it seems that the bed scene was eliminated in both productions, probably in the process of removing two characters from the play (Thomson, 'A Quarto "Marked for Performance", 196).

66 For the stage dimensions see Documents of the Rose Playhouse, revised edition, ed. Carol Chillington Rutter (Manchester, 1999), xii, xv.

67 Curiously and inexplicably, Martin Wiggins invariably classifies beds under 'Scenery' rather than 'Large Portable Objects' and under 'Staging' says there was a 'Discovery Space' ... 'set with a bed', thereby implying both that that beds were never put forward on stage and that there was a central opening in the tiring house wall. (Martin Wiggins, with Catherine Richardson, British Drama, 1533-1642: A Catalogue, 6 vols (Oxford, 2012-15)). 
68 See Thornton, Seventeenth-Century Interior Decoration, 161.

69 Hodges's conjectural drawings, which are also inevitably interpretive, include a variety of kinds of bed; for some examples see Enter the Whole Army, 104, 106, 109, 110.

70 Heywood, The Golden Age (1611; stc: 13325), I1v, I2r. This is the first stage direction for a bed to be 'drawn in'.

71 Cyril Tourneur, The Atheist's Tragedy (1611; stc: 24146), K2v; Richard Brome, $A$ Mad Couple Well Matched (1653; Wing: B4870), F5r, F6v.

72 John H. Astington, "Enter Imogen in her bed": Stage Directions and Pictorial Composition in the Bed Scene', an unpublished paper written for the 1995 Shakespeare Association of America theatre history seminar in Chicago. Quoted with permission.

73 According to G.K. Hunter, 'Flatcaps and Bluecoats', Essays and Studies 33 (1980), 'It is clear that beds, thrones, desks, etc. were pushed out on to the main stage after their "discovery" and there claimed their relationship to the world around them' (21). As I hope this study demonstrates, the staging of few if any bed scenes is this obvious or straightforward.

74 John Fletcher, Monsieur Thomas (1639; sTC: 11071), L1r, L2r. For a similar interpretation, see Hosley, 'Desdemona's Bed', 62-3.

75 The Golden Age, I2v.

76 A New Trick to Cheat the Devil, I4v.

77 Richard Brome, The City Wit (1653; Wing: B4866), C8r.

78 Antony and Cleopatra, zz2v; Four Plays in One, 8E2v.

79 But also possible is that a bed sometimes remained visible on stage as a kind of commentary and reminder after the bed scene had ended - as perhaps between 4.3 and 4.5 in Romeo and Juliet.

80 Tamburlaine, Part 2, D2r. This use of 'arras' in a bed scene is unique.

81 Lily B. Campbell, Scenes and Machines on the English Stage During the Renaissance (Cambridge, 1923; rpt New York, 1960), 136-40.

82 Reynolds, The Staging of Elizabethan Plays, 67-8.

83 Peter Thomson, Shakespeare's Theatre, second edn (London and New York, 1994), seems to echo Campbell's idea when he posits a 'mobile platform' for 'Volpone's bed [sic], or Desdemona's' (52); and Sasha Roberts, "Let me the curtains draw": the Dramatic and Symbolic Properties of the Bed in Shakespearean Tragedy', Jonathan Gil Harris and Natasha Korda (eds), Staged Properties in Early Modern English Drama, (Cambridge, 2002), 153-74 refers to large property beds 'prepared for ease of movement, perhaps upon a rolling stage' (157).

84 See Thornton, Seventeenth-Century Interior Decoration, 151. 
85 See Alan C. Dessen and Leslie Thomson, A Dictionary of Stage Directions in English Drama, 1580-1642 (Cambridge, 1999), entries for bed, nightgown, nightcap.

86 Unsurprisingly, no evidence indicates that a bed was ever located on the upper level.

87 See for example Measure for Measure, All's Well That Ends Well, and The Changeling.

88 See Frederick Kiefer, 'Curtains on the Shakespearean Stage', Medieval and Renaissance Drama in England, vol. 20 (2007), 152-8.

89 William Shakespeare, Romeo and Juliet (1597; sтC: 22322), I1r. See Romeo and Juliet, ed. Jill L. Levenson (Oxford, 2000), 4.3.57.1 note.

90 John Ford, 'Tis Pity She's a Whore (1633; stc: 11165), C3v, I4r.

91 Thomas Heywood, $A$ Woman Killed with Kindness (1607; sTc: 13371), F4r, H2v.

92 If this bed was 'thrust out' the stage would have been very full with a canopied bed and nine players, four of whom needed space to dance. But if the bed was in an opening in the tiring house wall, the ability of playgoers to see the action on the bed would have been seriously restricted.

93 Hosley says, 'Since Syphax is in the bed, the curtains which he opens are evidently bed-curtains. Hence the term canopy is apparently here used in the sense of 'hangings' (OED, I) to designate bed-curtains; and since the bed is Syphax's, the phrase "as to Sophonisbas bed" presumably means "as though it were Sophonisba in the bed"” ('Staging', 60, n 14). According to John Sturgess, 'At this stage, it is clear that the audience can see the bed and its occupants. Either it is set in the discovery-space or it has been set on the main stage between the acts. As the scene also requires the use of the stage trap and an altar, and the latter must also have been set between the acts, the discovery-space is the likely place' (John Marston, 'The Malcontent' and Other Plays, ed. John Sturgess (Oxford, 1997), 382). For what it's worth, I agree with Hosley.

94 John Marston, The Wonder of Women or the Tragedie of Sophonisba (1605; STC: 17488), B1v, B4v, D4v, E1r, F1v, F2r.

95 Francis Beaumont and John Fletcher, The Maid's Tragedy (1610; stc: 1677), I4v, K1r.

96 See The Maid's Tragedy, ed. T.W Craik (Manchester, 1988), 5.1.24 sd note.

97 Thomas Heywood, The Rape of Lucrece (1608; stc: 13360), G1v, G2r, G3r. Hosley says, 'Tarquin's carrying Lucrece off stage at the end of the action implies that the bed is not within a discovery-space, for if it were Lucrece would presumably be removed from the audience's view simply by a closing of the discovery-space curtains ... By definition the bed is curtained, and its curtains are alluded to in the dialogue. Hence the "discovery" of Lucrece apparently consists in opening the bedcurtains, the term discover being used in the same sense as in Marston's Wonder of Women' ('Staging', 60, n 14).

98 John Shirley, The Traitor (1635; sтc: 22458), K2v, K3v, L1v. 
99 William Rowley, All's Lost by Lust (1633; sтс: 21425), G4v.

100 Thomas Heywood, A Maidenhead Well Lost (1633; stc: 13357), G4r, H1v.

101 See also The Late Lancashire Witches (1634; sTC: 13373; Globe) and Love's Mistress (1635; sтC: 13352; Phoenix, Court). 
